\title{
Inhibitory Effect of Aqueous Extract of Moringa oleifera and Newbuoldia laevis Leaves on Ferrous Sulphate and Sodium Nitroprusside Induced Oxidative Stress in Rat's Testes in Vitro*
}

\author{
Seun F. Akomolafe ${ }^{1,2 \#}$, Ganiyu Oboh $^{2}$, Afolabi A. Akindahunsi ${ }^{2}$, Ayodele J. Akinyemi ${ }^{2,3}$, \\ Olusola Adeyanju ${ }^{4}$ \\ ${ }^{1}$ Department of Biochemistry, Ekiti State University, Ado Ekiti, Nigeria \\ ${ }^{2}$ Department of Biochemistry, Federal University of Technology, Akure, Nigeria \\ ${ }^{3}$ Department of Biochemistry, Afe Babalola University, Ado Ekiti, Nigeria \\ ${ }^{4}$ Department of Chemistry, University of Jos, Jos, Nigeria \\ Email: "purposefulseun@yahoo.co.uk
}

Received October 10, 2012; revised November 15, 2012; accepted November 26, 2012

\begin{abstract}
Oxidative stress has been identified as one of the factors that affects fertility status. Therefore, this study sought to investigate the inhibitory effect of aqueous extract of Moringa oleifera and Newbuoldia laevis leaves on $\mathrm{FeSO}_{4}$ and Sodium Nitroprusside (SNP) induced lipid peroxidation in rat testes in vitro. Incubation of the testes tissue homogenate in the presence of $\mathrm{FeSO}_{4}$ and SNP caused a significant increase in the malondialdehyde (MDA) contents of the testes. The aqueous extract from both Moringa oleifera and Newbuoldia laevis leaves caused a significant decrease in the MDA contents of the testes in a dose-dependent manner. However, aqueous extract from Moringa oleifera leaf $\left(\mathrm{EC}_{50}=0.29\right.$ $\mathrm{mg} / \mathrm{ml})$ had a significant $(\mathrm{P}<0.05)$ higher inhibitory effect on $\mathrm{Fe}^{2+}$ induced lipid peroxidation in the rat testes homogenate than that of Newbuoldia laevis leaf extract $\left(\mathrm{EC}_{50}=0.58 \mathrm{mg} / \mathrm{ml}\right)$; while there was no significant $(\mathrm{P}<0.05)$ difference between the plant extracts on SNP induced lipid peroxidation in the rat testes homogenates. Therefore, part of the mechanisms through which the water extractable phytochemicals in the leaves protect the testes from oxidative stress may be through their antioxidant activity; DPPH scavenging ability, $\mathrm{Fe}^{2+}$ chelating and reducing power. Therefore, these plants have potential to prevent oxidative stress in testes and improve fertility outcomes.
\end{abstract}

Keywords: Lipid Peroxidation; Malondialdehyde; Antioxidant Activity; Testes

\section{Introduction}

Infertility is a major clinical problem, affecting people medically and psychosocially. Published literature data indicates that $15 \%$ of all couples in the United States are infertile, and the male factor is responsible for $25 \%$ of these cases [1]. In many cases the cause of male infertility, oxidative stress (OS) has been identified as one of the major factors that affects fertility status and thus, has been extensively studied in recent years. Spermatozoa, like any other aerobic cell, are constantly facing the "oxygen-paradox" [2]. Oxygen is essential to sustain life as physiological levels of reactive oxygen species (ROS) are necessary to maintain normal cell function [3]. Conversely, breakdown products of oxygen such as ROS can be detrimental to cell function and survival [4]. Reactive oxygen species are present as free radicals. Examples of

*No competing financial interests exist.

\#Corresponding author.
ROS include the hydroxyl superoxide radical, hydrogen peroxide, peroxyl radical, and hypochlorite ion. These are the common forms of ROS that have been considered injurious to sperm survival and function when present in abundance.

Although iron is necessary physiologically as components of many enzymes and proteins, free iron in the cytosol and mitochondria could cause considerable oxidative damage by acting catalytically in the production of ROS which have the potential to damage cellular lipids, nucleic acids, proteins and carbohydrate resulting in wide ranging impairment in cellular function and integrity [5]. The mechanism by which iron can cause this deleterious effect is that $\mathrm{Fe}$ (II) can react with hydrogen peroxide $\left(\mathrm{H}_{2} \mathrm{O}_{2}\right)$ to produce the hydroxyl radical $(\mathrm{OH})$ via the Fenton reaction, whereas superoxide can react with iron (III) to regenerate iron (II) that can participate in the Fenton reaction [6]. The overproduction of ROS can lead 
to direct attack on the polyunsaturated fatty acids of the cell membranes and induce lipid peroxidation. The mammalian spermatozoa are rich in polyunsaturated fatty acids (PUFA) and thus, are very susceptible to ROS attack which results in a decrease sperm motility [7].

Sodium nitroprusside (SNP) is an anti-hypertensive drug, which acts by relaxing smooth vascular muscle; consequently it dilates peripheral arteries and veins. However, it could cause cytotoxicity through the release of cyanide ion and/or nitric oxide (NO). ROS can directly attack the polyunsaturated fatty acids of the cell membranes and induce lipid peroxidation. Malondialdehyde (MDA) is the end product of lipid peroxidation, which is a process where reactive oxygen species (ROS) degrade polyunsaturated fatty acids. MDA is a reactive aldehyde and is one of the many reactive electrophile species that cause toxic stress in cells. The production of this aldehyde is used as a biomarker to measure the level of oxidative stress in an organism [8].

Recently, a lot of attention has been focused on the role of the antioxidative defense system in fighting oxidative stress $[9,10]$. Endogeneous antioxidants in plants may play an important role in antioxidative defense against oxidative damage [11], possibly preserving the biological functions of cells [12]. There is increasing interest in the protective biological function of natural antioxidants contained in dietary plants, which are candidates for the prevention of oxidative damage $[13,14]$. These antioxidants are polyphenolic compounds, which are found in all plants and in all parts of the plants (tree bark, stalks, leaves, fruits, roots, flowers, pods and seeds) [14].

Phenolic compounds are an important group of secondary metabolites, which are synthesized by plants because of plant adaptation to biotic and abiotic stress condition such as infection, water stress, and cold stress [15]. In recent years, phenolic compounds have attracted the interest of researchers because of their antioxidants capacity; they can protect the human body from free radicals, which are formed due to normal natural metabolism in aerobic cells. The antiradical activity of flavonoids and phenolics is principally based on the structural relationship between different parts of their chemical structure [16]. Polyphenolics are common constituents of the human diet, present in most foods and beverages of plant origin. They are considered to contribute to the prevention of various degenerative diseases. This assumption originally came from in vitro studies, showing the antioxidant properties of several polyphenolics and their ability to modulate the activity of various enzymes. Research suggests that many flavonoids are more potent antioxidant than vitamins $\mathrm{C}$ and $\mathrm{E}[17,18]$.

Moringa oleifera, also called horse radish or drumstick tree and known by many native names in Nigeria such as zogalle (in Hausa), okweoyibo (in Igbo), eweigbake (in Yoruba) and dogalla (in Taroh), belongs to the monogeneric family Moringaceae [19]. M. oleifera is well known for its nutritional as well as medicinal values by many communities in Northern Nigeria. The leaf of this plant is used as vegetable in soup preparation or cooked and mixed with grounded groundnut cake and other spices. Medicinally, the plant was reported to exhibit anti-inflammatory, antihypertensive and anti-ulcer activities [20,21]. The plant is also well known for its use in traditional therapies as abortifacient and infertility control [22]. Phytochemical investigation on the plant revealed the presence of moringine and moringinine alkalodis in the root; pterygospermine alkaloid in the flower, fatty acids and fixed oils in the seed.

Newbuoldia laevis (Bignoniaceae) commonly known as African Border tree (Hausa-Aduruku or Bareshi, IgboOgirisie, Yoruba-Akoko) is used for therapeutic purpose against a number of diseases. In Ivory Coast and Nigeria, stem bark decoctions of $N$. laevis is used for the treatment of epilepsy and convulsions in children [23]. After pulping, as a paste, the bark is used for treatment of rheumatism, especially for the painful arthritis of the knees [23]. In Nigeria, decoctions of leaves and roots made from boiling are used in the treatment of breast tumors and improve male fertility [24]. Although a lot had been reported on the chemical characterization of phytoconstituents and antioxidant properties of $M$. oleifera and $N$. laevis, there is still limited information on its potential use in the management and prevention of infertility diseases associated with oxidative stress. Hence, the objective of this study is to investigate the inhibitory effect of water extractable phytochemicals from Moringa oleifera and Newbuoldia laevis leaves on $\mathrm{Fe}^{2+}$ and SNP induced lipid peroxidation in rat testes in vitro.

\section{Materials and Methods}

\subsection{Collection and Identification of Plant Samples}

Fresh samples of Moringa oleifera and Newbuoldia laevis leaves were purchased in Akure metropolis, Nigeria. Authentication of the leaves was carried out in the Department of Plant Science, Ekiti State University, Ado Ekiti, Nigeria. The voucher specimen number given were UHAE 332 and UHAE 331 for Moringa oleifera and Newbuoldia laevis leaves respectively.

\subsection{Chemicals and Reagents}

Chemicals and reagents used such as thiobarbituric acid (TBA), 1,10-phenanthroline, deoxyribose, gallic acid, Folin-Ciocalteau's reagent were procured from SigmaAldrich, Inc., (St Louis, MO), trichloroacetic acid (TCA) was sourced from Sigma-Aldrich, Chemie GmbH (Stein- 
heim, Germany), dinitrophenyl hydrazine (DNPH) from ACROS Organics (New Jersey, USA), hydrogen peroxide, methanol, acetic acid and $\mathrm{FeCl}_{3}$ were sourced from BDH Chemicals Ltd., (Poole, England), thiourea,

$\mathrm{CuSO}_{4} \cdot 5 \mathrm{H}_{2} \mathrm{O}, \mathrm{H}_{2} \mathrm{SO}_{4}$, sodium carbonate, $\mathrm{AlCl}_{3}$, potassium acetate, Tris- $\mathrm{HCl}$ buffer, sodium dodecyl sulphate, $\mathrm{FeSO}_{4}$, potassium ferricyanide and ferric chloride were of analytical grade while the water was glass distilled.

\subsection{Aqueous Extract Preparation}

The samples were washed under running water, air dried after which the dried samples were ground to powder and kept dry in an air-tight container prior to the extraction. 1 $\mathrm{g}$ each of the samples was weighed into $20 \mathrm{~mL}$ of distilled water and was left for 24 hours [25]. The mixture after 24 hours was filtered and the filtrate centrifuged at $805 \times \mathrm{g}$ for 10 minutes. The clear supernatant collected was used for the assay.

\subsection{Determination of Total Phenolic Content}

The total phenolic content was determined on the extracts using the method reported by Singleton et al. [26]. Appropriate dilutions of the extracts were oxidized with $2.5 \mathrm{~mL}$ of $10 \%$ Folin-Ciocalteau's reagent (v/v) and neutralized by $2.0 \mathrm{~mL}$ of $7.5 \%$ sodium carbonate The reaction mixture was incubated for 40 minutes at $45^{\circ} \mathrm{C}$ and the absorbance was measured at $765 \mathrm{~nm}$ in the spectrophotometer (JENWAY 6305, Barloworld Scientific, Dunmow, United Kingdom). The total phenolic content was subsequently calculated as gallic acid equivalent using gallic acid standard curve.

\subsection{Determination of Total Flavonoid Content}

The total flavonoid content of both extracts was determined using a slightly modified method reported by Meda et al. as described below briefly [27]. $0.5 \mathrm{~mL}$ of appropriately diluted sample was mixed with $0.5 \mathrm{~mL}$ methanol, $50 \mu \mathrm{L} 10 \% \mathrm{AlCl}_{3}, 50 \mu \mathrm{L} 1 \mathrm{M}$ Potassium acetate and $1.4 \mathrm{~mL}$ water, and allowed to incubate at room temperature for 30 minutes. The absorbance of the reaction mixture was subsequently measured at $415 \mathrm{~nm}$ and the total flavonoid content was subsequently calculated using quercetin standard curve.

\subsection{Determination of Vitamin C Content}

Vitamin C content of the water extracts was determined using the method of Benderitter et al. as described below briefly [28]. $75 \mu \mathrm{L}$ DNPH (2 g dinitrophenyl hydrazine, $230 \mathrm{mg}$ thiourea and $270 \mathrm{mg} \mathrm{CuSO} \cdot 5 \mathrm{H}_{2} \mathrm{O}$ in $100 \mathrm{~mL}$ of $\left.5 \mathrm{M} \mathrm{H}_{2} \mathrm{SO}_{4}\right)$ were added to $500 \mu \mathrm{L}$ reaction mixture (300 $\mu \mathrm{L}$ of an appropriate dilution of the polar extract with $100 \mu \mathrm{L} 13.3 \%$ trichloroacetic acid (TCA) and water).
The reaction mixtures were subsequently incubated for 3 $\mathrm{h}$ at $37^{\circ} \mathrm{C}$, then $0.5 \mathrm{~mL}$ of $65 \% \mathrm{H}_{2} \mathrm{SO}_{4}(\mathrm{v} / \mathrm{v})$ was added to the medium; followed by absorbance measurment at 520 $\mathrm{nm}$. The vitamin $\mathrm{C}$ content of the samples was subsequently calculated as ascorbic acid equivalent.

\subsection{Lipid Peroxidation Assay}

\subsubsection{Experimental Animals}

Male Wistar albino rats weighing between 190 and $250 \mathrm{~g}$ were purchased from the Central Animal House, Department of Biochemistry, University of Ilorin, Ilorin, Nigeria. They were housed in stainless steel cages under controlled conditions of a 12-hour light/dark cycle, $50 \%$ humidity, and $28^{\circ} \mathrm{C}$ temperature. The rats were allowed asses to food and water ad libitum. The animals were used in accordance with the procedure approved by the Animal Ethics Committee of the Federal University of Technology, Akure, Nigeria.

\subsubsection{Preparation of Tissue Homogenates}

The rats were decapitated under mild diethyl ether anaesthesia and the testes (tissue) were rapidly dissected and placed on ice and weighed. This tissue was subsequently homogenized in cold saline $(1 / 10 \mathrm{w} / \mathrm{v})$ with about 10 strokes at approximately $1200 \mathrm{rev} / \mathrm{min}$ in a Teflon glass homogenizer (Mexxcare, mc14 362, Aayushi Design Pvt. Ltd., India). The homogenate was centrifuged (KX3400C Kenxin Intl. Co. Hong Kong) for 10 minutes at $3000 \times \mathrm{g}$ to yield a pellet that was discarded, and a low-speed supernatant (SI), which was kept for lipid peroxidation assay [29].

\subsection{Lipid Peroxidation and Thiobarbibutric Acid Reactions}

The lipid peroxidation assay was carried out using the modified method of Ohkawa et al. as described below briefly [30]. $100 \mu \mathrm{L}$ of the SI fraction was mixed with a reaction mixture containing $30 \mu \mathrm{L}$ of $0.1 \mathrm{M}$ pH 7.4 Tris- $\mathrm{HCl}$ buffer, extract $(100 \mu \mathrm{L})$ and $30 \mu \mathrm{L}$ of $25 \mu \mathrm{M}$ freshly prepared $\mathrm{FeSO}_{4}$. The volume was made up to 300 $\mu \mathrm{L}$ by water before incubation at $37^{\circ} \mathrm{C}$ for 2 hours. The color reaction was developed by adding $300 \mu \mathrm{L} 8.1 \%$ SDS (Sodium dodecyl sulphate) to the reaction mixture containing SI, this was subsequently followed by the addition of $600 \mu \mathrm{L}$ of acetic acid/HCl (pH 3.4) mixture and $600 \mu \mathrm{L}$ of $0.8 \%$ Thiobarbituric acid (TBA). This mixture was incubated at $100^{\circ} \mathrm{C}$ for 1 hour. Thiobarbituric acid reactive species (TBARS) produced were measured at $532 \mathrm{~nm}$ and expressed as Malondialdehyde (MDA) produced (\% control) using Malondialdehyde standard curve $(0-0.035 \mathrm{mM})$.

\subsection{DPPH Free Radical Scavenging Ability}

The free radical scavenging ability of the extracts against 
DPPH (1,1-diphenyl-2 picrylhydrazyl) free radical was evaluated as described by Gyamfi et al. [31]. Briefly, an appropriate dilution of the extracts $(1 \mathrm{~mL})$ was mixed with $1 \mathrm{~mL}$ of $0.4 \mathrm{mM}$ methanolic solution containing DPPH radicals, the mixture was left in the dark for 30 min and the absorbance was measured at $516 \mathrm{~nm}$. The control was carried out using $2 \mathrm{~mL}$ DPPH solution without the test samples. The DPPH free radical scavenging ability was subsequently calculated.

DPPH scavenging ability (\%) $=[($ Absorbance of Control - Absorbance of Samples)/Absorbance of Control] $\times$ 100 .

\subsection{0. $\mathrm{Fe}^{2+}$ Chelation Assay}

The $\mathrm{Fe}^{2+}$ chelating ability of both extracts were determined using a modified method of Minotti and Aust [32] with a slight modification by Puntel et al., [33]. Freshly prepared $500 \mu \mathrm{M} \mathrm{FeSO}{ }_{4}(150 \mu \mathrm{L})$ was added to a reaction mixture containing $168 \mu \mathrm{L}$ of $0.1 \mathrm{M}$ Tris- $\mathrm{HCl}(\mathrm{pH}$ 7.4), $218 \mu \mathrm{L}$ saline and the extracts $(0-25 \mu \mathrm{L})$. The reaction mixture was incubated for $5 \mathrm{~min}$, before the addition of $13 \mu \mathrm{L}$ of $0.25 \%$ 1,10-phenanthroline (w/v). The absorbance was subsequently measured at $510 \mathrm{~nm}$ in a spectrophotometer. The Fe (II) chelating ability was subsequently calculated with respect to the reference (which contains all the reagents without the test sample).

\subsection{Determination of Reducing Property}

The reducing property of the extracts was determined by assessing the ability of the extract to reduce $\mathrm{FeCl}_{3}$ solution as described by Oyaizu [34]. A $2.5 \mathrm{~mL}$ aliquot was mixed with $2.5 \mathrm{~mL}$ of $200 \mathrm{mM}$ sodium phosphate buffer (pH 6.6) and $2.5 \mathrm{~mL}$ of $1 \%$ potassium ferricyanide. The mixture was incubated at $50^{\circ} \mathrm{C}$ for $20 \mathrm{~min}$ and then 2.5 $\mathrm{mL}$ of $10 \%$ trichloroacetic acid was added. This mixture was centrifuged at $650 \mathrm{rpm}$ for $10 \mathrm{~min} .5 \mathrm{~mL}$ of the supernatant was mixed with an equal volume of water and $1 \mathrm{~mL}$ of $0.1 \%$ ferric chloride. The absorbance was measured at $700 \mathrm{~nm}$. The ferric reducing antioxidant property was subsequently calculated using ascorbic acid as standard.

\subsection{Data Analysis}

The results of the replicates were pooled and expressed as mean \pm standard deviation. Analysis of variance and the $t$-test were carried out [35]. Significance was accepted at $\mathrm{P} \leq 0.05$.

\section{Results and Discussion}

\subsection{Vitamin C, Total Phenolic and Flavonoid Contents}

Many plants are rich sources of phytochemicals, and in- takes of these plant chemicals have protective potential against degenerative diseases [36]. The vitamin $\mathrm{C}$ content of Moringa oleifera and Newbuoldia laevis leaves is presented in Table 1. The result revealed that there was no significant $(\mathrm{P}<0.05)$ different between the vitamin $\mathrm{C}$ content of Moringa oleifera and Newbuoldia laevis leaves. Vitamin $\mathrm{C}$ has been reported to contribute to the antioxidant activities of plant food. Ascorbic acid is a good reducing agent and exhibits its antioxidant activities by electron donation [17,37]. It helps the immune system to fight off infections and tumor cells, supports the cardiovascular system by facilitating fat metabolism and protecting tissues from free radical damage, and it assists the nervous system by converting certain amino acids into neurotransmitters. As a water-soluble antioxidant, vitamin $\mathrm{C}$ is in a unique position to "scavenge" aqueous peroxyl radicals before these destructive substances damage the lipids [38]. The vitamin $C$ content of the leaves is higher than that of related spices such as basil, bird pepper, black pepper, cinnamon, nutmeg, oregano, parsley and rosemary [39], and some commonly consumed green leafy vegetables in Nigeria $[17,34]$, green and red pepper [23] and some commonly consumed and underutilized tropical legumes [40]. It is also worth noting that the vitamin $\mathrm{C}$ content of the leaf is higher than its total phenolic content. The high vitamin $\mathrm{C}$ content of the leafy spices will definitely contribute additively or synergistically to the observed antioxidant and medicinal properties of the leaves.

Furthermore, the total phenolic content of Moringa oleifera leaves $(13.1 \mathrm{mg} / \mathrm{g})$ had a significantly $(\mathrm{P}<0.05)$ higher total phenolic content than Newbuoldia laevis $(11.1 \mathrm{mg} / \mathrm{g})$. However, the values obtained are lower than what was reported for some hot peppers [25] and green teas [41], but higher than ginger varieties [42] and some tropical leafy vegetables. Phenolic compounds can protect the human body from free radicals. They are strong antioxidants capable of removing free radicals, chelate metal catalysts, activate antioxidant enzymes, reduce alpha-tocopherol radicals and inhibit oxidases [43]. Also, the total flavonoid content of Moringa oleifera leaf $(0.11$ $\mathrm{mg} / \mathrm{g})$ was significantly $(\mathrm{P}<0.05)$ higher than Newbuoldia laevis leaf $(0.093 \mathrm{mg} / \mathrm{g})$. However, the values

Table 1. Total Phenolic, flavonoid and vitamin $C$ content of Moringa oleifera and Newbuoldia laevis leaves.

\begin{tabular}{cccc}
\hline & $\begin{array}{c}\text { Phenolic } \\
\text { content }(\mathrm{mg} / \mathrm{g})\end{array}$ & $\begin{array}{c}\text { Flavonoid } \\
\text { content }(\mathrm{mg} / \mathrm{g})\end{array}$ & $\begin{array}{c}\text { Vitamin C } \\
(\mathrm{mg} / \mathrm{g})\end{array}$ \\
\hline $\begin{array}{c}\text { Moringa } \\
\text { oleifera }\end{array}$ & $13.1^{\mathrm{a}} \pm 0.63$ & $0.110^{\mathrm{b}} \pm 0.00$ & $24.0^{\mathrm{c}} \pm 0.09$ \\
$\begin{array}{c}\text { Newbuoldia } \\
\text { laevis }\end{array}$ & $11.1^{\mathrm{b}} \pm 0.25$ & $0.093^{\mathrm{c}} \pm 0.00$ & $25.3^{\mathrm{d}} \pm 0.01$ \\
\hline
\end{tabular}

Values represent means \pm standard deviation of triplicate readings. Superscripts with the same letters along the same column are not significantly different $(\mathrm{P}>0.05)$. 
obtained are lower than what was reported for tropical clove bud [44] and some tropical green leafy vegetables [45]. The presence of derivatives of flavonoids has been found in many spices; moreover, numerous studies have conclusively shown that the majority of the antioxidant activity may be from compounds such as flavonoids, isoflavones, flavones, anthocyanins, catechin and isocatechin rather than from vitamins $\mathrm{C}, \mathrm{E}$ and $\beta$-carotene [46]. Flavonoids have antioxidant activity and could therefore lower cellular oxidative stress. Polyphenols are considered to be strong antioxidants due to the redox properties of their hydroxyl groups [47].

\subsection{Inhibition of $\mathrm{Fe}^{2+}$ Induced Lipid Peroxidation}

Lipids are considered to be the most susceptible macromolecules and are present in male reproductive organ. One of the byproducts of lipid peroxidation is malondialdehyde, this byproduct has been used in various biochemical assays to monitor the degree of peroxidative damage sustained by spermatozoa $[48,49]$. Testicular toxicity due to $\mathrm{Fe}^{2+}$ impairs fertility [50]. The finding that $\mathrm{Fe}^{2+}$ caused a significant increase in the MDA content of the testes homogenate agreed with earlier report where $\mathrm{Fe}^{2+}$ was shown to be a potent initiator of lipid peroxidation [25]. The increased lipid peroxidation in the presence of $\mathrm{Fe}^{2+}$ could be attributed to the fact that $\mathrm{Fe}^{2+}$ can catalyze one-electron transfer reactions that generate reactive oxygen species, such as the reactive $\mathrm{OH}^{\circ}$, which is formed from $\mathrm{H}_{2} \mathrm{O}_{2}$ through the Fenton reaction. Iron also decomposes lipid peroxides, thus generating peroxyl and alkoxyl radicals, which favors the propagation of lipid oxidation [51]. In the testes, Fe induced lipid peroxidation destroys the structure of lipid matrix in the membranes of spermatozoa, and it is associated with loss of motility and impairment of spermatogenesis [52]. Therefore, possible depletion of iron could decrease oxidative stress throughout the whole body. The ability of the water extractible phytochemicals from Moringa oleifera and Newbuoldia laevis leaves to inhibit $\mathrm{Fe}^{2+}$ induced lipid peroxidation in the testes homogenate is presented in Figure 1. The result revealed that incubation of the testes homogenate in the presence of $\mathrm{Fe}^{2+}$ caused a significant increase in the MDA content of the rat testes homogenate $(137.5 \%)$ when compared with the basal testes homogenate $(100 \%)$. However, the aqueous extract from Moringa oleifera and Newbuoldia laevis leaves inhibited MDA production in rat's testes in a dose-dependent manner $(0-0.63 \mathrm{mg} / \mathrm{ml})$. Nevertheless, judging by the $\mathrm{EC}_{50}$ (extract concentration causing $50 \%$ enzyme inhibition) values in Table 2, Moringa oleifera leaf $\left(\mathrm{EC}_{50}=\right.$ $0.29 \mathrm{mg} / \mathrm{ml}$ ) had a significantly higher inhibitory effect on $\mathrm{Fe}^{2+}$ induced lipid peroxidation in the testes homogenate than Newbuoldia laevis leaf $\left(\mathrm{EC}_{50}=0.58 \mathrm{mg} / \mathrm{ml}\right)$. The

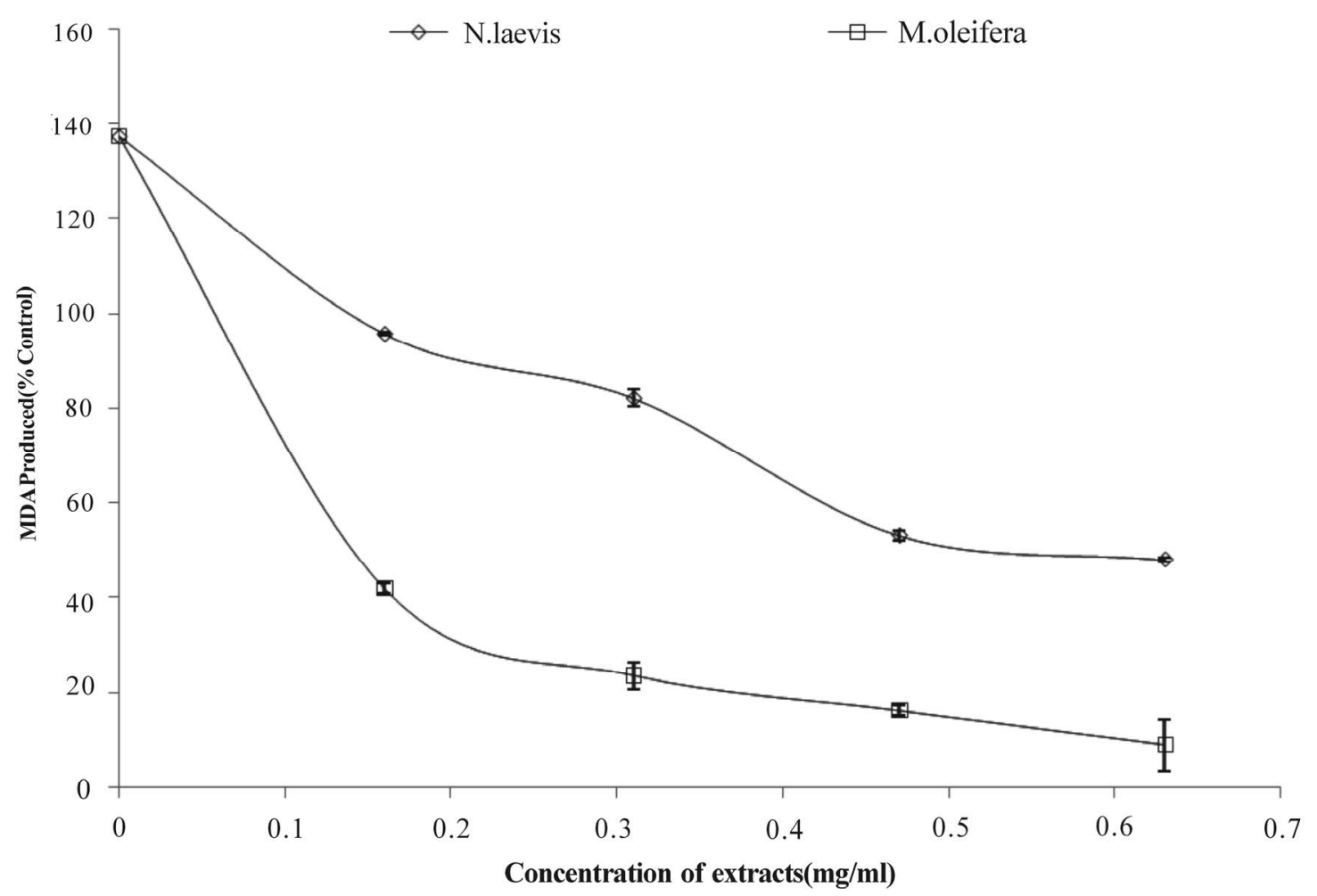

Figure 1. Inhibition of $\mathrm{Fe}^{2+}$ induced lipid peroxidation in rat testes by aqueous extract of Moringa oleifera and Newbuoldia laevis leaves. 
decrease in the $\mathrm{Fe}^{2+}$ induced lipid peroxidation in the rat testes homogenates in the presence of the extracts could be as the result of the ability of the extracts to chelate $\mathrm{Fe}^{2+}$ and/or scavenge free radicals produced by the $\mathrm{Fe}^{2+}$ catalyzed production of reactive oxygen species (ROS) in the rat testes.

\subsection{DPPH Radical Scavenging and $\mathrm{Fe}^{2+}$ Chelating Assay}

Antioxidants carry out their protective role on cells either by preventing the production of free radicals or by neutralizing/scavenging free radicals produced in the body or by reducing/chelating the transition metal composition of foods $[53,54]$. In an attempt to explain the main mechanism through which the water extractable phytochemicals in the plant extracts protect testes tissue against $\mathrm{Fe}^{2+}$ induced lipid peroxidation, the DPPH radical scavenging and $\mathrm{Fe}^{2+}$ chelating abilities were assessed.

The prevention of the chain initiation step by scavenging various reactive species such as free radicals is considered to be an important antioxidant mode of action [55]. DPPH is a free radical donor that accepts an electron or hydrogen to become a stable diamagnetic molecule [56]. The tendencies of electron or hydrogen donation are critical factors in characterizing antioxidant ac- tivity that involves free radical scavenging [57]. Foods of plant origin usually contain natural antioxidants that can scavenge free radicals [14]. The DPPH radical scavenging ability of the aqueous extract from Moringa oleifera and Newbuoldia laevis leaves as represented in Figure 2 revealed that both extracts scavenged DPPH radicals in a dose-dependent manner $(0-3.33 \mathrm{mg} / \mathrm{ml})$.

Both plant extracts chelate $\mathrm{Fe}^{2+}$ at the concentration of the extracts tested with Moringa oleifera leaf extract better chelator than Newbuoldia laevis leaf extract (Figure 3). This result however, is in agreement with the $\mathrm{Fe}^{2+}$ induced lipid peroxidation (Figure 1), phenolic content (Table 1) and antioxidant activity of the extracts, suggesting that $\mathrm{Fe}^{2+}$ chelation may be one of the possible mechanisms through which antioxidant phytochemicals from Moringa oleifera and Newbuoldia laevis leaf extracts prevent lipid peroxidation in tissue by forming a complex with $\mathrm{Fe}^{2+}$, thus preventing the initiation of lipid peroxidation.

\subsection{Ferric Reducing Ability}

Furthermore, the reducing power of the extractable phytochemicals from Moringa oleifera and Newbuoldia laevis leaf expressed as ascorbic acid equivalent (AAE) is presented in Figure 4. The result revealed that aqueous

Table 2. $\mathrm{EC}_{50}$ values of Inhibition of $\mathrm{Fe}^{2+}$ and SNP induced lipid peroxidation in rat testes by aqueous extract of $\mathrm{Moringa}$ oleifera and Newbuoldia laevis leaves.

\begin{tabular}{ccc}
\hline Samples & $\mathrm{EC}_{50}(\mathrm{mg} / \mathrm{ml}) \mathrm{Fe}^{2+}$ induced lipid peroxidation & $\mathrm{EC}_{50}(\mathrm{mg} / \mathrm{ml}) \mathrm{SNP}$ induced lipid peroxidation \\
\hline Moringa oleifera & $0.29 \pm 0.01$ & $0.25 \pm 0.00$ \\
Newbuoldia laevis & $0.58 \pm 0.01$ & $0.25 \pm 0.00$ \\
\hline
\end{tabular}

Values represent mean \pm standard deviation, number of samples $n=3$.

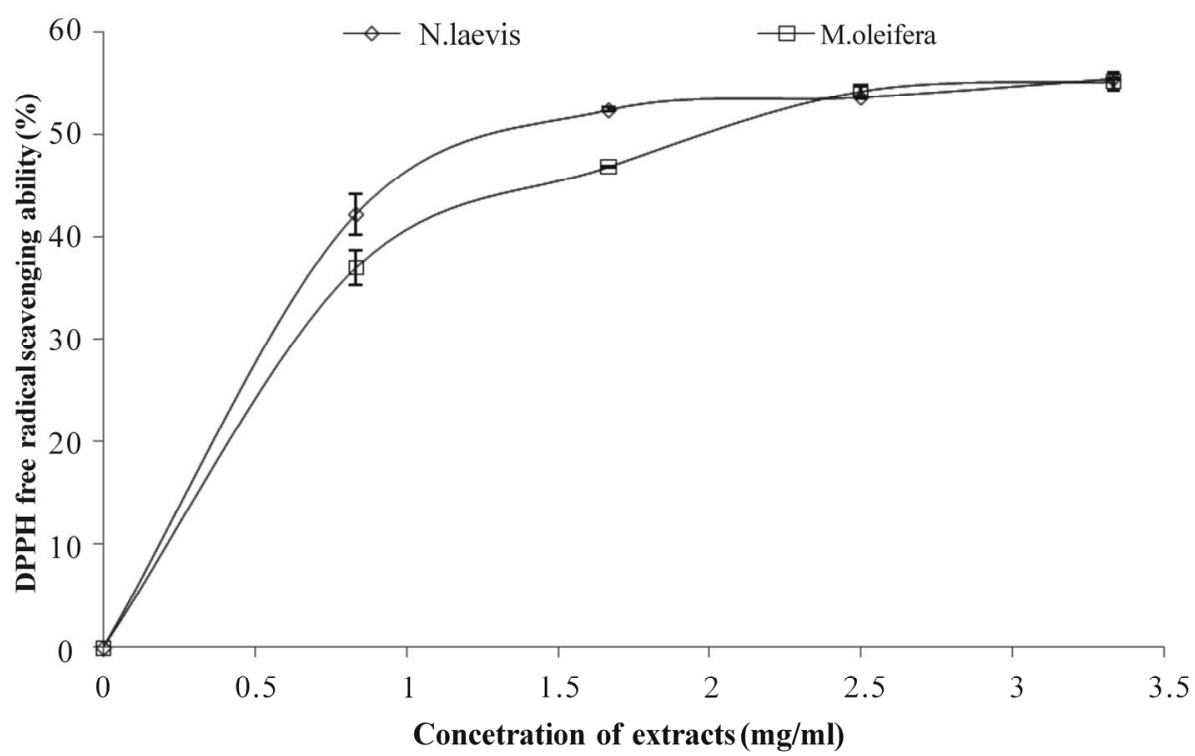

Figure 2. DPPH radical scavenging ability of aqueous extract of Moringa oleifera and Newbuoldia laevis leaves. 


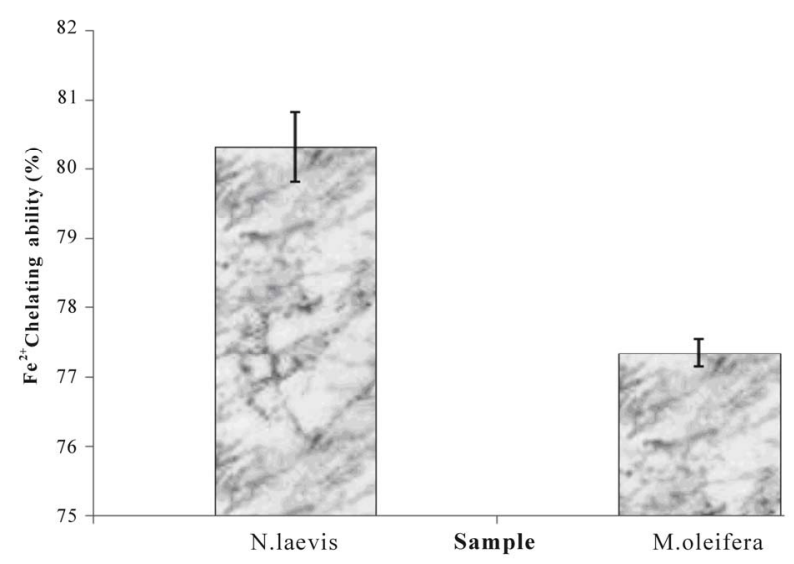

Figure 3. $\mathrm{Fe}^{2+}$ chelating ability of aqueous extract of Moringa oleifera and Newbuoldia laevis leaves.

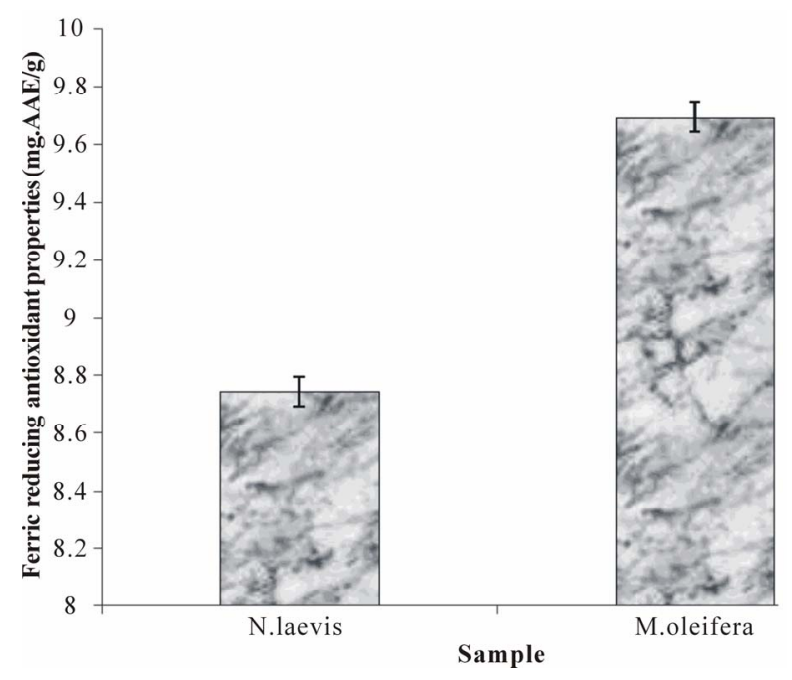

Figure 4. Ferric reducing antioxidant properties (FRAP) of aqueous extract of Moringa oleifera and Newbuoldia laevis leaves.

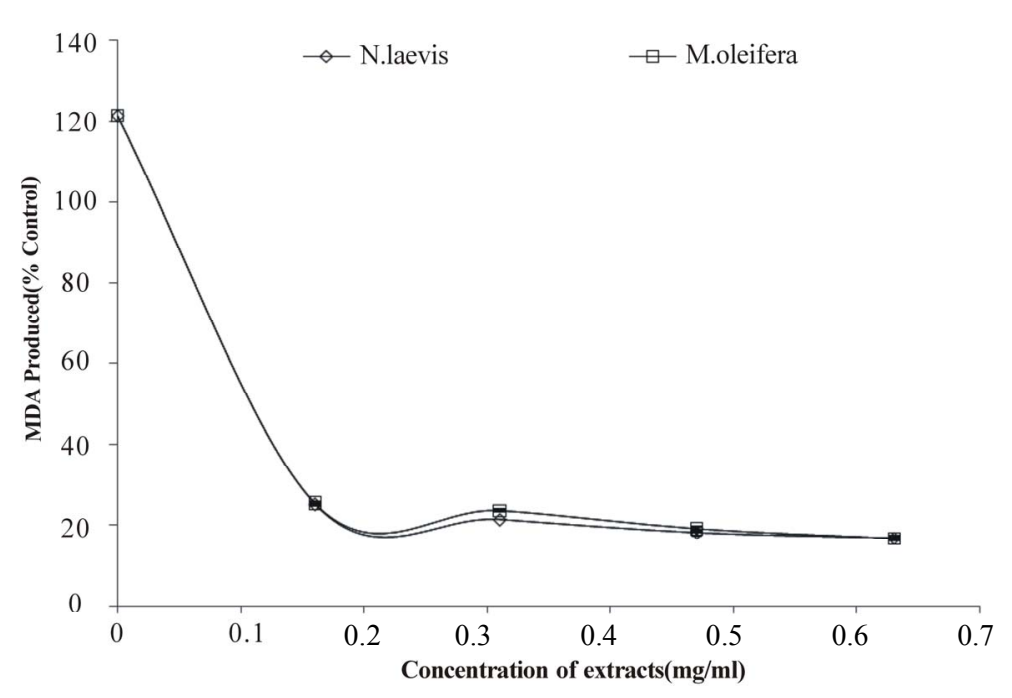

Figure 5. Inhibition of SNP induced lipid peroxidation in rat testes by aqueous extract of Moringa oleifera and Newbuoldia laevis leaves. reducing power than aqueous extract of Newbuoldia laevis leaf. The reducing power as characterized by the ability of the plant extracts to reduce $\mathrm{Fe}^{3+}$ to $\mathrm{Fe}^{2+}$ is a potent antioxidation defense mechanism, and two mechanisms available to affect this reducing power is by electron transfer and hydrogen atom transfer [16]. Allhorn et al. [58] reported that the reducing property can be a novel antioxidation defense mechanism, possibly through the ability of the antioxidant compound to reduce ferric ion. Therefore, the higher reducing ability of the Moringa oleifera leaf extract may have contributed to the greater protective effect observed. The higher reducing power of the Moringa oleifera leaf may be related to the higher water extractable antioxidant phytochemicals present in it (Table 1).

\subsection{Inhibition of SNP Induced Lipid Peroxidation}

Likewise, incubation of rat's testes tissue homogenates in the presence of sodium nitroprusside also caused a significant increase in the rat testes malondialdehyde (MDA) content as shown in Figure 5; however, both extracts inhibited MDA production content in both tissues in a dose-dependent $(0-0.63 \mathrm{mg} / \mathrm{ml})$. However, judging by $\mathrm{t}$ he $\mathrm{EC}_{50}$ value in Table 2, there was no significant difference between the aqueous extract of Moringa oleifera and Newbuoldia laevis leaves. The protective properties of the plant extracts against sodium nitroprusside induced lipid peroxidation in the testes could be because of the ability of the antioxidant phytochemicals present in the aqueous extract to quench-scavenge the nitrous radical and Fe produced from the decomposition of sodium nitroprusside. 


\section{Conclusion}

The aqueous extract of Moringa oleifera and Newbuoldia laevis leaves were able to protect the testes homogenate from $\mathrm{Fe}^{2+}$ and SNP induced lipid peroxidation in vitro. And part of the mechanisms through which the water extractable phytochemicals in the leaves protect the testes from oxidative stress may be through their antioxidant activity; DPPH scavenging ability, $\mathrm{Fe}^{2+}$ chelating and reducing power. Therefore, rat testes stress could be potentially managed/prevented by these plant extracts and can prove useful infertility treatment.

\section{REFERENCES}

[1] I. D. Sharlip, J. P. Jarow, A. M. Belker, L. I. Lipshultz, M. Sigman and A. J. Thomas, "Best Practice Policies for Male Infertility," Fertility and Sterility, Vol. 77, No. 5, 2002, pp. 873-882. doi:10.1016/S0015-0282(02)03105-9

[2] H. Sies, "Strategies of Antioxidant Defense," European Journal of Biochemistry, Vol. 215, No. 2, 1993, pp. 213219. doi:10.1111/j.1432-1033.1993.tb18025.x

[3] Z. G. Badade and P. M. Samant, "Role of Oxidative Stress in Male Infertility," Journal of Biomedical Sciences and Research, Vol. 3, No. 2, 2011, pp. 385-391.

[4] E. de Lamirande and C. Gagnon, "Impact of Reactive Oxygen Species on Spermatozoa: A Balancing Act between Beneficial and Detrimental Effects," Human Reproduction, Vol. 10, No. 1, 1995, pp. 15-21. doi:10.1093/humrep/10.suppl_1.15

[5] R. S. Britton, K. L. Leicester and B. R. Bacon, "Iron Toxicity and Chelation Therapy," International Journal of Hematology, Vol. 76, No. 3, 2002, pp. 219-228. doi:10.1007/BF02982791

[6] M. P. Zago, S. V. Verstraeten and P. I. Oteiza, "Zinc in the Prevention of $\mathrm{Fe}^{2+}$ Initiated Lipid and Protein Oxidation," Biological Research, Vol. 33, No. 2, 2000, pp. 143150. doi:10.4067/S0716-97602000000200014

[7] J. Aitken, C. Krausz and D. Buckingham, "Relationships between Biochemical Markers for Residual Sperm Cytoplasm, Reactive Oxygen Species Generation, and the Presence of Leukocytes and Precursor Germ Cells in Human Sperm Suspensions," Molecular Reproduction and Development, Vol. 39, No. 3, 1994, pp. 268-279. doi: $10.1002 / \mathrm{mrd} .1080390304$

[8] R. K. Murray, D. K. Granner, P. A. Mayes and V. W. Rodwell, "Harper's Biochemistry," 25th Edition, The McGraw-Hill Companies, New York, 2000, p. 927.

[9] Y. Sugiyama, S. Kawakishi and T. Osawa, "Involvement of the B-Diketone Moiety in the Antioxidative Mechanism of Tetrahydrocurcumin," Biochemical Pharmacology, Vol. 52, No. 4, 1996, pp. 519-525. doi:10.1016/0006-2952(96)00302-4

[10] T. Tsuda, K. Shiga, K. Ohshima, S. Kawakishi and T. Osawa, "Inhibition of Lipid Peroxidation and the Active Oxygen Radical Scavenging Effect of Anthocyanin Pigments Isolated from Phaseolus vulgaris L.," Biochemical
Pharmacology, Vol. 52, No. 7, 1996, pp. 1033-1039. doi:10.1016/0006-2952(96)00421-2

[11] M. Naito, M. Kuzuya and A. Iguchi, "Mechanisms of Endothelial Cell Injury Induced by Oxidatively Modified LDL," Journal of Japan Atherosclerosis Society, Vol. 22, 1994, pp. 257-262.

[12] M. Naito, T. Hayashi and A. Iguchi, "New Approaches to the Prevention of Atherosclerosis," Drugs, Vol. 50, No. 3, 1995, pp. 440-453. doi:10.2165/00003495-199550030-00003

[13] E. N. Frankel, J. Kanner, J. B. German, E. Parks and J. E. Kinsella, "Inhibition of Oxidation of Human Low-Density Lipoprotein (1988): Antioxidant Defenses and Lipid Preoxidation in Human Blood Plasma," Proceedings of the National Academy of Sciences, Vol. 85, No. 24, 1993, pp. 9748-9752.

[14] T. Osawa, S. Yoshida, K. Yamashida and H. Ochi, "Protective Role of Dietary Antioxidants in Oxidative Stress," In: R. G. Cutler, L. Packer, J. Bertram and A. Mori, Eds., Oxidative Stress and Aging, Birkhauser-Verlag, Basel, 1995, pp. 367-377.

[15] G. Oboh and J. B. T. Rocha, "Polyphenols in Red Pepper [Capsicum Annuum Var. Aviculare (Tepin)] and Their Protective Effect on Some Pro-Oxidants Induced Lipid Peroxidation in Brain and Liver," European Food Research and Technology, Vol. 225, No. 2, 2007, pp. 239247. doi:10.1007/s00217-006-0410-1

[16] C. Rice-Evans, N. J. Miller and G. Paganga, "StructureAntioxidant Activity Relationships of Flavonoids and Phenolic Acids," Free Radicals in Biology and Medicine, Vol. 20, No. 7, 1996, pp. 933-956. doi:10.1016/0891-5849(95)02227-9

[17] G. Oboh, "Polyphenol Extracts from Hyptis suaveolens Leaves Inhibit $\mathrm{Fe}^{2+}$-Induced Lipid Peroxidation in Brain," International Journal of Biomedical and Pharmaceutical Sciences, Vol. 2, No. 1, 2008, pp. 41-46.

[18] G. Oboh and A. A. Akindahunsi, "Change in the Ascorbic Acid, Total Phenol and Antioxidant Activity of Some Sun-Dried Green Leafy Vegetables in Nigeria," Nutrition and Health, Vol. 18, No. 1, 2004, pp. 29-36. doi: $10.1177 / 026010600401800103$

[19] H. Fahey, "Moringa oleifera, a Review of the Medical Evidence for Its Nutritional, Therapeutic, and Prophylactic Properties," Trees for Life Journal, Vol. 1, 2000, p. 5.

[20] T. C. Ezeamuzie, A. W. Amberkedeme, F. O. Shode and S. C. Ekwebelem, "Anti-Inflammatory Effects of M. oleifera Root," International Journal of Pharmacognosy, Vol. 34, No. 93, 1996, pp. 207-212. doi:10.1076/phbi.34.3.207.13211

[21] S. K. Pal, P. K. Mukherjee and B. P. Saham, "Studies on the Anti-Ulcer Activity of M. oleifera Leaf Extracts on Gastric Ulcer Models in Rats," Phytotherapy Research, Vol. 9, No. 6, 1995, pp. 463-465.

[22] M. Oommachan and S. S. Khan, "Plants in Aid of Family Planning," Ancient Science of Life, Vol. 1, No. 1, 1981, pp. 64-66.

[23] H. M. Burkill, "The Useful Plants of West Tropical Africa," 2nd Edition, Royal Botanic Gardens, Kew, London, 
1985.

[24] H. M. Burkill, "The Useful Plants of West Tropical Africa," 2nd Edition, Royal Botanic Gardens, London, 1997.

[25] G. Oboh, R. L. Puntel and J. B. T. Rocha, "Hot Pepper (Capsicum annuum, Tepin and Capsicum chinese, Habanero) Prevents $\mathrm{Fe}^{2+}$-Induced Lipid Peroxidation in Brain-in Vitro," Food Chemistry, Vol. 102, No. 1, 2007, pp. 178185. doi:10.1016/j.foodchem.2006.05.048

[26] V. L. Singleton, R. Orthofer and R. M. Lamuela-Raventos, "Analysis of Total Phenols and Other Oxidation Substrates and Antioxidants by Means of Folin-Ciocalteu Reagent," Academic Press, San Diego, 1999.

[27] A. Meda, C. E. Lamien, M. Romito, J. Millogo and O. G. Nacoulma, "Determination of the Total Phenolic, Flavonoid and Proline Contents in Burkina Faso Honey, as Well as Their Radical Scavenging Activity," Food Chemistry, Vol. 91, No. 3, 2005, pp. 571-577. doi:10.1016/j.foodchem.2004.10.006

[28] M. Benderitter, V. Maupoil, C. Vergely, F. Dalloz, F. Briot and L. Rochette, "Studies by Electron Paramagnetic Resonance of the Importance of Iron in Hydroxyl Scavenging Properties of Ascorbic Acid in Plasma Effects of Iron Chelators," Fundamental \& Clinical Pharmacology, Vol. 12, No. 5, 1998, pp. 510-516. doi:10.1111/j.1472-8206.1998.tb00979.x

[29] N. A. V. Belle, G. D. Dalmolin, G. Fonini, M. A. Rubim and J. B. T. Rocha, "Polyamines Reduces Lipid Peroxidation Induced by Different Pro-Oxidant Agents," Brain Research, Vol. 1008, No. 2, 2004, pp. 245-251. doi:10.1016/j.brainres.2004.02.036

[30] H. Ohkawa, N. Ohishi and K. Yagi, "Assay for Lipid Peroxides in Animal Tissues by Thiobarbituric Acid Reaction," Analytical Biochemistry, Vol. 95, No. 2, 1979, pp. 351-358. doi:10.1016/0003-2697(79)90738-3

[31] M. A. Gyamfi, M. Yonamine and Y. Aniya, "Free-Radical Scavenging Action of Medicinal Herbs from Ghana: Thonningia Sanguinea on Experimentally-Induced Liver Injuries," General Pharmacology, Vol. 32, No. 6, 1999, pp. 661-667. doi:10.1016/S0306-3623(98)00238-9

[32] G. Minotti and S. D. Aust, "An Investigation into the Mechanism of Citrate-Fe ${ }^{2+}$-Dependent Lipid Peroxidation," Free Radical Biology and Medicine, Vol. 3, No. 6, 1987, pp. 379-387. doi:10.1016/0891-5849(87)90016-5

[33] P. R. L. Untel, C. W. Nogueira and J. B. T. Rocha, "Krebs Cycle Intermediates Modulate Thiobarbituric Reactive Species (TBARS) Production in Rat Brain in Vitro," Neurochemical Research, Vol. 30, No. 2, 2005, pp. 225-235. doi:10.1007/s11064-004-2445-7

[34] M. Oyaizu, "Studies on Products of Browning Reaction: Antioxidative Activity of Products of Browning Reaction Prepared from Glucosamine," Japanese Journal of Nutrition, Vol. 44, No. 6, 1986, pp. 307-315. doi:10.5264/eiyogakuzashi.44.307

[35] J. H. Zar, "Biostatistical Analysis," Prentice-Hall, Inc., Upper Saddle River, 1984.

[36] Y. Chu, J. Sun, X. Wu and R. H. Liu, "Antioxidant and Antiproliferative Activity of Common Vegetables," Journal of Agricultural and Food Chemistry, Vol. 50, No. 23,
2002, pp. 6910-6916. doi:10.1021/jf020665f

[37] G. Oboh, "Effect of Blanching on the Antioxidant Property of Some Tropical Green Leafy Vegetables," Lebensmittel Wissenschaft und Technologie, Vol. 38, No. 5, 2005, pp. 513-517. doi:10.1016/j.lwt.2004.07.007

[38] E. Kronhausen, P. Kronhausen, B. Harry and M. D. Demopoulos, "Formula for Life," William Morrow and Co., Inc., New York, 1989.

[39] L. Calucci, C. Pinzino, M. Zandomeneghi, A. Capocchi, S. Ghiringhelli, F. Saviozzi, S. Tozzi and L. Galleschi, "Effects of ç-Irradiation on the Free Radical and Antioxidant Contents in Nine Aromatic Herbs and Spices," Journal of Agricultural and Food Chemistry, Vol. 51, No. 4, 2003, pp. 927-934. doi:10.1021/jf020739n

[40] G. Oboh, "Antioxidant Properties of Some Commonly Consumed and Underutilized Tropical Legumes," European Food Research and Technology, Vol. 244, No. 1, 2006, pp. 61-65. doi:10.1007/s00217-006-0289-x

[41] G. Oboh and J. B. T. Rocha, "Water Extractable Phytochemicals from Capsicum pubescens (Tree Pepper) Inhibit Lipid Peroxidation Induced by Different Pro-Oxidant Agents in Brain in Vitro," European Food Research and Technology, Vol. 226, No. 4, 2008, pp. 707-713. doi:10.1007/s00217-007-0580-5

[42] G. Oboh, A. J. Akinyemi and A. O. Ademiluyi, "Antioxidant and Inhibitory Effect of Red Ginger (Zingiber officinale var. Rubra) and White Ginger (Zingiber officinale Roscoe) on $\mathrm{Fe}^{2+}$ Induced Lipid Peroxidation in Rat Brain in Vitro," Experimental and Toxicologic Pathology, Vol. 64, No. 1-2, 2012, pp. 31-36. doi:10.1016/j.etp.2010.06.002

[43] D. Amic, D. Davidovic-Amic, D. Beslo and N. Trinajstic, "Structure-Radical Scavenging Activity Relationship of Flavonoids," Croatia Chemical Acta, Vol. 76, No. 1, 2003, pp. 55-61.

[44] A. O. Ademiluyi, V. O. E. Akpambang and G. Oboh, "Polyphenol Contents and Antioxidant Capacity of Tropical Clove Bud (Eugenia aromatica Kuntze)," The Italian Magazine of Fatty Substances, Vol. 86, No. 2, 2009, pp. 131-137.

[45] G. Oboh, H. Raddatz and T. Henle, "Antioxidant Properties of Polar and Non-Polar Extracts of Some Tropical Green Leafy Vegetables," Journal of the Science of Food and Agriculture, Vol. 88, No. 14, 2008, pp. 2486-2492. doi:10.1002/jsfa.3367

[46] A. Marin, F. Ferreres, F. A. Tomas-Barberan and M. I. Gil, "Characterization and Quantitation of Antioxidant Constituents of Sweet Pepper (Capsicum annuum L.)," Journal of Agricultural and Food Chemistry, Vol. 52, No. 12, 2004, pp. 3861-3869. doi:10.1021/jf0497915

[47] M. Materska and I. Perucka, "Antioxidant Activity of the Main Phenolic Compounds Isolated from Hot Pepper Fruits (Capsicum annum L.)," Journal of Agricultural and Food Chemistry, Vol. 53, 2005, pp. 1730-1758. doi:10.1021/jf035331k

[48] R. J. Aitken, D. Harkiss and D. W. Buckingham, “Analysis of Lipid Peroxidation Mechanisms in Human Spermatozoa," Molecular Reproduction and Development, Vol. 
35, No. 3, 1993, pp. 302-315. doi:10.1002/mrd.1080350313

[49] J. Aitken and H. Fisher, "Reactive Oxygen Species Generation and Human Spermatozoa: The Balance of Benefit and Risk," Bioessays, Vol. 16, No. 4, 1994, pp. 259-267. doi:10.1002/bies.950160409

[50] K. Narayana, "An Aminoglycocide Antibiotic Gentamycin Induces Oxidative Stress, Reduces Antioxidant Reserve and Impairs Spermatogenesis in Rats," The Journal of Toxicological Sciences, Vol. 33, No. 1, 2008, pp. 85-96. doi: $10.2131 /$ jts. 33.85

[51] M. P. Zago, S. V. Verstraeten and P. I. Oteiza, "Zinc in the Prevention of $\mathrm{Fe}^{2+}$ Initiated Lipid and Protein Oxidation," Journal of Biological Research, Vol. 33, No. 2, 2000, pp. 143-150. doi:10.4067/S0716-97602000000200014

[52] Y. Minamiyama, S. Takemura, S. Kodai, H. Shinkawa, T. Tsukiola, H. Ichikawa, Y. Naito, T. Yoshikawa and S. Okada, "Iron Restriction Improves Type 2 Diabetes Mellitus in Otsuka Long-Evans Tokushima Fatty Rats," American Journal of Physiology-Endocrinology and Metabolism, Vol. 298, No. 6, 2010, pp. 1140-1149. doi:10.1152/ajpendo.00620.2009

[53] M. Alia, C. Horcajo, L. Bravo and L. Goya, "Effect of Grape Antioxidant Dietary Fiber on the Total Antioxidant Capacity and the Activity of Liver Antioxidant Enzymes in Rats," Nutrition Research, Vol. 23, No. 9, 2003, pp.
1251-1267. doi:10.1016/S0271-5317(03)00131-3

[54] D. Amic, D. Davidovic-Amic, D. Beslo and N. Trinajstic, "Structure-Radical Scavenging Activity Relationship of Flavonoids," Croatica Chemica Acta, Vol. 76, No. 1, 2003, pp. 55-61.

[55] K. Dastmalchi, H. J. D. Dorman, M. Kosar and R. Hiltunen, "Chemical Composition and in Vitro Antioxidant Evaluation of a Water Soluble Moldavian Balm (Dracocephalum moldavica L.) Extract," LWT-Food Science and Technology, Vol. 40, No. 2, 2007, pp. 239-248. doi:10.1016/j.lwt.2005.09.019

[56] J. Y. Je, P. J. Park, E. K. Kim and C. B. Ahn, "Antioxidant and Angiotensin I Converting Enzyme Inhibitory Activity of Bambusae caulis in Liquamen," Food Chemistry, Vol. 113, No. 4, 2009, pp. 932-935. doi:10.1016/j.foodchem.2008.08.022

[57] C. Hu, Y. Zhang and D. D. Kitts, "Evaluation of Antioxidant and Prooxidant Activities of Bamboo Phyllostachys niger var. Henonis Leaf Extract in Vitro," Journal of Agricultural and Food Chemistry, Vol. 48, No. 8, 2000, pp. 3170-3176. doi:10.1021/if0001637

[58] M. Allhorn, A. Klapyta and B. Akerstrom, "Redox Properties of the Lipocalin Alpha1 Microglobulin: Reduction of Cytochrome C, Hemoglobin, and Free Iron," Free Radical Biology and Medicine, Vol. 38, No. 5, 2005, pp. 557 567. doi:10.1016/j.freeradbiomed.2004.12.013 